\title{
Analysis of blood stream infections: Antimicrobial susceptibility and associated types of extended spectrum $\beta$-lactamases
}

\author{
Lorina I Badger-Emeka ${ }^{1 *}$, Zainab Yaseen Al-Jaziri², Naheed Kausar ${ }^{1}$, Nora \\ Ahmad Al-Muhainy ${ }^{2}$, Edric Estrella ${ }^{3}$ \\ ${ }^{1}$ Department of Biomedical Sciences, College of Medicine, ${ }^{2}$ College of Medicine, ${ }^{3}$ Department of Public health, College of \\ Applied Medical Sciences, King Faisal University. Al-Ahsa. Kingdom of Saudi Arabia \\ *For correspondence: Email: Ibadgeremeka@kfu.edu.sa, lorinaineta@gmail.com
}

Sent for review: 19 April 2020

Revised accepted: 25 May 2020

\begin{abstract}
Purpose: To investigate the antimicrobial susceptibility and extended spectrum $\beta$-lactamase (ESBL) production by clinical isolates of Escherichia coli (ESBL-EC) and Klebsiella species (ESBL-KP) associated with blood stream infections (BSIs).

Methods: Bacteria isolation and identification were carried out using basic bacteriological and biochemical techniques. Antimicrobial susceptibility test was performed according to the guidelines of the Clinical Laboratory Standard Institute (CLSI). Vitek 2 Compact automated system was used to confirm the identifications (ID) and antimicrobial susceptibility test (AST). The ESBL produced by E. coli and K. pneumoniae isolates were phenotypically characterised using Modified Double Disc Synergy Test (MDDST), as recommended by CLSI.

Results: All (100 \%) isolates were sensitive to imipenem and meropenem, while susceptibility to other antibiotics varied. ESBL genotypes, viz, blaтем, blasHV and blactx were encountered in the BSIs. For ESBL-EC, TEM, SHV and CTX producers accounted for 33, 16.67 and $58.3 \%$, respectively, while 75, 91.7 and $100 \%$ of ESBL-KP were TEM, SHV and CTX producers, respectively. In ESBL-KP, $67 \%$ coexisted with all three genotypes (blatem, blashv, and blactx, while $8.3 \%$ of ESBL-EC coexisted with the three encoding genes (CTX, SHV and TEM).

Conclusion: ESBL E. coli and K. pneumoniae associated with BSI have been identified as TEM, SHV and CXT producers, with more ESBL-KP coexisting with all three than ESBL-EC.
\end{abstract}

Keywords: $\beta$-Lactamases, Genes, Klebsiella pneumoniae, Escherichia coli

\begin{abstract}
This is an Open Access article that uses a fund-ing model which does not charge readers or their institutions for access and distributed under the terms of the Creative Commons Attribution License (http://creativecommons.org/licenses/by/4.0) and the Budapest Open Access Initiative (http://www.budapestopenaccessinitiative.org/read), which permit unrestricted use, distribution, and reproduction in any medium, provided the original work is properly credited.
\end{abstract}

Tropical Journal of Pharmaceutical Research is indexed by Science Citation Index (SciSearch), Scopus, International Pharmaceutical Abstract, Chemical Abstracts, Embase, Index Copernicus, EBSCO, African Index Medicus, JournalSeek, Journal Citation Reports/Science Edition, Directory of Open Access Journals (DOAJ), African Journal Online, Bioline International, Open-J-Gate and Pharmacy Abstracts

\section{INTRODUCTION}

Treatable bacterial infections are not considered as leading causes of death in patients. However, clinicians are encountering difficulties in treating bacterial infections globally, due to the emergence of multidrug-resistant bacteria (MDR), more so with bacteria associated with blood stream infections (BSIs). The frequency of isolation of BSI varies globally, and also within geographical regions [1]. However, cases of BSIs are under-reported, indicating that many of them 
are not included in the World Health Organization (WHO) list of most reported causes of death [2]. The annual reported neonatal deaths from BSIs is put at about 2.9 million in low income countries [4].

There is also a global increase in the emergence of extended-spectrum beta-lactamase (ESBL)producing Enterobacteriaceae which constitutes a high risk in healthcare-associated infections, including blood stream infections. This is of high significance due the role of ESBL producers as leading factors in morbidity and mortality. However, there is a general dearth of information on ESBL-BSIs due to under-reporting of incidents of BSIs, and the fact that when results were available, they were associated with inconsistency [3]. In England, Wilson et al [4] reported increased cases of BSIs up to 2006, followed by a decline therefrom to 2008 . Moreover, available data for Danish population covered up to 2008 [5], while in Finland [6], increases in cases of BSIs covered up to 2007. Overall, a European surveillance study [7] has suggested an increase in cases of BSls up to 2008. These reports point to either underreporting of cases within the indicated periods, or a complete control of BSIs in these regions. However, in Saudi Arabia, reports on the incidence of BSIs have spanned over a period of two decades from 1983 [8] to a more recent date [9].

These reports imply that continuous attention is being drawn to BSIs generally in various regions in the Kingdom of Saudi Arabia, more so with its strategic location associated with high antimicrobial resistance. Al-Otaibi et al [10] gave an update on the prevalence of Gram-negative bacilli associated with BSIs in hospitalized patients with malignancy at an oncology unit in Riyadh. The report may be considered scanty since it did not include infections of blood stream attributed to ESBL-producing Enterobacteriaceae (ESBL-E) [11].

These infections have limited options for treatment, since they exhibit MDR to aminoglycosides and fluoroquinolones, thereby creating limited therapeutic options for clinicians. Therefore, it is not unlikely that patients are managed with inappropriate empirical therapy that would subsequently lead to an increase in morbidity and mortality. Another study investigated the risk factors associated with mortality in adult patients with ESBL-BSIs, and reported a three-fold increase in mortality resulting from inadequately-treated patients, relative to adequately-treated group of patients [12]. Beta-lactam antibiotics are placed amongst the safest and most frequently prescribed antibacterial drugs worldwide [13]. This has led to persistent bacterial exposure to $\beta$-lactams, and subsequent mutations in the TEM, SHV, CTX-M genes of Escherichia coli and Klebsiella pneumoniae, the main ESBL producers [14,15].

The ESBLs belong to the molecular class A [15]. They are able to hydrolyze penicillins as well as third-generation cephalosporins and monobactams. It has been reported that CTX-M is the most common genetic variant of ESBL initially encountered in E. coli [15]. The SHV-1 encoding gene is chromosomally generated within Klebsiella pneumoniae responsible for resistance to broad-spectrum penicillins (ampicillin, tigecycline and piperacillin) [13]. This gene was later reported to have been incorporated into plasmids, with subsequent spread to other Enterobacteriaceae [13]. The TEM-1 was first reported in $E$. coli isolates. However, Klebsiella oxytoca harboring plasmidmediated encoding TEM-12 gene was first reported in England in 1982 [14].

The presence of ESBLs such as ampicillinhydrolyzing TEM-1 and SHV-1 $\beta$-lactamases in Escherichia coli and Klebsiella pneumoniae, and in other members of the Enterobacteriaceae is of immerse microbiological and clinical importance. Moreover, the fact that these $\beta$-lactamases can spread to other pathogenic bacteria is of major public health concern. The resultant effect on mortality is evident in septic shock and organ failure, with $K$. pneumoniae producing more severe effects than any other Enterobacteriaceae [16]. To tackle the global problem created by drug-resistant bacteria, there is need for regular and concise reporting of global and regional surveillance, with a view to aiding rational use of antibiotic therapy. The present investigation studied the bacterial isolates associated with blood stream infections, their antimicrobial susceptibilities, and ESBL production of clinical isolates of Escherichia coli and Klebsiella species associated with blood infections.

\section{EXPERIMENTAL}

\section{Ethical consideration}

Permission for this research was obtained from the Postgraduate and Research Committee of College of Medicine KFU (approval code 18-02$19 \mathrm{~B})$.

\section{Bacteria isolation and characterisation}

The ESBL-producing Escherichia coli and Klebsiella spp bacteria isolates were used for this 
investigation. They were samples responsible for blood stream infections in hospitalised patients, and were collected for routine diagnosis required for patients care. All isolates were given laboratory IDs as shown in Tables 4 and 5 . Bacteria isolation and their characterization were done using basic bacteriological and biochemical techniques. In the microbiology laboratory at the College of Medicine, further identification and confirmation of the clinical isolates were carried out using VITEK 2 compact automated system (BioMerieux, Marcy L'Etoile, France). Gram negative (GN) and antimicrobial susceptibility test (AST) cards were used for ID and antimicrobial susceptibility testing, respectively, according to the manufacturers' guidelines. The following antibiotics were used for the susceptibility test: ampicillin $(10 \mu \mathrm{g})$, aztreonam $(30 \mu \mathrm{g})$, cefotaxime $(30 \mu \mathrm{g})$, ceftriaxone $(30 \mu \mathrm{g})$, ceftazidime $(30 \mu \mathrm{g})$, cefepime $(30 \mu \mathrm{g})$, cefuroxime $(30 \mu \mathrm{g})$, cephalotin $(30 \mu \mathrm{g})$, gentamicin $(10 \mu \mathrm{g})$, amikacin $(30 \mu \mathrm{g})$, ciprofloxacin $(5 \mu \mathrm{g})$, piperacillin/tazobactam $(100 / 10 \mu g)$, tobramycin $(10 \mu g)$, meropenem (10 $\mu \mathrm{g})$, and imipenem $(10 \mu \mathrm{g})$.

\section{Screening for ESBLs}

The ESBL produced by each of the isolates resistant to ceftriaxone and cefotaxime was phenotypically characterised using the modified double disc synergy test [MDDST] as recommended by CLSI [17]. Fresh cultures of the isolates were plated out on Muller-Hilton agar and discs of amoxicillin-clavulanate (20/10 $\mu \mathrm{g})$ along with the four cephalosporins: 3GCcefotaxime, ceftriaxone, cefpodoxime and 4GCcefepime. The method described by Kaur et al 18] was used for separating the distances between the 3GC and 4GC discs, with amoxicillin clavulanate disc $(20 / 10 \mu \mathrm{g})$ placed at the centre of the plate. The results were interpreted as described by CSLI [19] and Kaur et al [18]. Resistance to single test against cefotaxime and ceftazidime alone, and separately in combination with clavulanate were used as confirmatory tests. An increase in inhibition zone in the amoxicillinclavulanate disc was interpreted as positive for ESBLs production. The positive and negative control strains for ESBLs production were ATCC E. coli 25922 and ATCC K. pneumoniae 70060, respectively. Only the ESBL producers were used for the investigation, out the 48 collected blood isolates.

\section{Molecular analysis}

Extraction and amplification of DNA were carried out using QIAgen DNA extraction kit (Qiagen, Germany) according to the manufacturer's guidelines, using fresh cultures of overnightgrown ESBL-EC and ESBL-KP BSIs samples. The PCR amplification of blatem, blashv and blactх-м genes was carried out for each of the isolates, while the presence of encoding ESBL gene of the resulting PCR products was visualised with agarose gel electrophoresis stained with ethidium bromide, using the primers shown in Table 1 [20-22]. A complete linkage cluster analysis was performed using Stata MP Version 13.

\section{Statistical analysis}

Data are presented as frequencies and proportions. An online MEDCALC statistical software was used for comparison of proportions. Values of $p<0.05$ were considered statistically significant. GraphPad statistical software and STATA 12 SE- 64 software were used for cluster analysis.

\section{RESULTS}

\section{Antimicrobial susceptibility}

The results of antimicrobial resistance of $E$. coli and $K$. pneumoniae ESBLs isolates against antibiotic groups are shown in Figure 1. All (100 $\%)$ bacteria isolates investigated were resistant to the cephalosporins and monobactams. All $K$. pneumoniae BSls were resistant to the penicillins, and also showed high resistance (72 $\%)$ to aminoglycoside. There was an observed variability in their antimicrobial sensitivities, with two-tailed test showing that the difference in antimicrobial resistance was not quite statistically significant between ESBL-EC and ESBL-KP. For aminoglycosides, although mean resistance of 42 and $72 \%$ were observed for ESBL-EC and $E S B L-K P$, respectively, this difference was also not statistically significant. Similarly, for the fluoroquinolones, resistance values of 92 and 75 $\%$ were obtained for ESBL $E$. coli and ESBL $K$. pneumoniae respectively. Mean resistance of ESBL-EC to the penicillins was high (86 \%), while all the ESBL-KP were intrinsically resistant to this group of antibiotics. However, all isolates were sensitive to the carbapenems. The results in Table 2 show that the BSIs were from male (50\%) and female (50\%) hospital wards, and ICU (42\%). The ages of the patients ranged from 8 months to 76 years.

\section{Molecular profile}

The genotypes TEM, SHV and CTX were found to be associated with ESBL-producing E. coli and K. pneumoniae BSIs, either alone or sometimes in coexistence of two or three of them. The CTX 
gene was the most predominant in all (100\%) of the ESBL-KP isolates, while SHV and TEM were in 97.67 and $75 \%$ of the isolates, respectively (Table 3). For the ESBL-EC, the CTX gene was predominant in $67 \%$ of the isolates, while 33.33 and $17 \%$ of the isolates carried SHV and TEM genes, respectively. The difference between the number of ESBL phenotypes in ESBL-EC and ESBL-KP was statistically significant $(p<0.0001$; Table 3).

As regards the number of ESBL-producing genes encountered in the $E$. coli isolates, coexistence of all three i.e. blatem, blashv and blactx. was observed in $8.3 \%$ of ESBL-EC, with an associated antimicrobial resistance of $76.47 \%$ (Table 4). Isolates E5 and E11 with recorded resistance of 82.35 and $76.47 \%$, respectively, carried none of the three genes. Moreover, $E$. coli (E1) with a resistance of $82.35 \%$ had only CTX associated with it. A large number of $K$. pneumoniae isolates $(67 \%)$ coexisted with all three genes (blatem, blashv and blactx), and resistance ranged between 76.47 - $88.24 \%$ among these ESBL-KP BSIs. The remaining 33
$\%$ of ESBLs K. pneumoniae coexisted with either TEM or SHV, together with CTX, and the observed antimicrobial resistance ranged between $64.71-76.47 \%$ (Table 5).

Results of analysis of the phylogenetic relatedness of ESBL-EC and ESBL-KP is shown in the dendrogram cluster (Figure 2). This analysis places all the isolates into 5 clades signifying dissimilarities between them, all based on resistance to the $\beta$-lactams against which they had been tested. Clade 1 consisted of E11, $\mathrm{E} 9, \mathrm{E} 2, \mathrm{~K} 9, \mathrm{~K} 1, \mathrm{~K} 7$, and $\mathrm{KO} 1$, and showed similar susceptibilities to six different antibacterial agents namely amikacin, amoxicillin plus clavulanic acid, ciprofloxacin, gentamicin, tazocin and tobramycin. Clade 2 (E8 and E7) had similar susceptibilities to amikacin, amoxicillin plus clavulanic acid and tazocin. Results shown in Figure 2 placed the remaining isolates into different clades, all of which were based on their susceptibilities to antimicrobials against which they had been tested.

Table 1: Nucleotide sequence of primers used for the study

\begin{tabular}{lll}
\hline Primer & Nucleotide sequence (5'- 3') & Reference \\
\hline TEM-F & AGATCAGTTGGGTGCACGAG & Yazdi et al [22] \\
TEM-R & CAGTGCTGCAATGATACCG & Yazdi et al [22] \\
CTX-M-U1 & ATGTGCAGYACCAGTAARGTKATGGC & Mulvey et al [23] \\
CTX-M-U2 & TGGGTRAARTARGTSACCAGAAYCAGCGG & Mulvey et al [23] \\
SHV-F & GGGTTATTCTTATTTGTCGC & Sima et al [24] \\
SHV-R & TTAGCGTTGCCAGTGCTC & Sima et al [24] \\
\hline
\end{tabular}

Table 2: ESBL-producing blood isolates from patients, ward of isolation and antimicrobial resistance

\begin{tabular}{|c|c|c|c|c|c|c|c|c|c|}
\hline \multicolumn{4}{|c|}{ ESBL-producing Escherichia coli } & \multicolumn{6}{|c|}{ ESBL-producing Klebsiella pneumoniae } \\
\hline $\begin{array}{l}\text { Lab } \\
\text { ID }\end{array}$ & Gender & $\begin{array}{c}\text { Age } \\
\text { (years) }\end{array}$ & Ward & $\begin{array}{c}\text { Resistance } \\
(\%)\end{array}$ & $\begin{array}{l}\text { Lab } \\
\text { ID }\end{array}$ & Gender & $\begin{array}{c}\text { Age } \\
\text { (years) }\end{array}$ & Ward & $\begin{array}{c}\text { Resistance } \\
(\%)\end{array}$ \\
\hline EC 1 & $\mathrm{~F}$ & 50 & Ward & 82.35 & KP 1 & $\mathrm{~F}$ & 8Months & Ward & 76.47 \\
\hline EC 2 & M & 60 & $\mathrm{ICU}$ & $\begin{array}{l}76.47 \\
58.82\end{array}$ & KP 2 & $\mathrm{~F}$ & 34 & ICU & $\begin{array}{l}76.47 \\
76.47\end{array}$ \\
\hline EC 3 & M & $\begin{array}{c}14 \\
\text { months }\end{array}$ & Ward & $\begin{array}{l}58.82 \\
82.35\end{array}$ & KP 3 & M & 8Months & Ward & $\begin{array}{l}76.47 \\
88.24\end{array}$ \\
\hline EC 4 & $\mathrm{~F}$ & 29 & $\mathrm{ICU}$ & 58.82 & KP 4 & M & 60 & Ward & 82.35 \\
\hline EC 5 & M & 76 & Ward & $\begin{array}{l}70.59 \\
70.59\end{array}$ & KP 5 & $M$ & 30 & ICU & $\begin{array}{l}64.71 \\
82.35\end{array}$ \\
\hline EC 6 & $F$ & 76 & Ward & 76.47 & KP 6 & $M$ & 30 & Ward & 82.35 \\
\hline EC 7 & $M$ & 68 & Ward & $\begin{array}{l}58.82 \\
76.47\end{array}$ & KP 7 & $\mathrm{M}$ & 72 & ICU & $\begin{array}{l}83.35 \\
76.47\end{array}$ \\
\hline EC 8 & $M$ & 68 & Ward & 70.59 & KP 8 & $\mathrm{M}$ & 77 & ICU & 82.35 \\
\hline EC 9 & $M$ & 35 & ICU & & KP 9 & $M$ & 77 & ICU & \\
\hline $\begin{array}{l}\text { EC } \\
10\end{array}$ & $M$ & 43 & ICU & & $\begin{array}{c}\mathrm{KP} \\
10\end{array}$ & $M$ & 33 & Ward & \\
\hline $\begin{array}{l}\mathrm{EC} \\
11\end{array}$ & $M$ & 35 & Ward & & $\begin{array}{c}\mathrm{KP} \\
11\end{array}$ & $M$ & 23 & Ward & \\
\hline $\begin{array}{l}\mathrm{EC} \\
12\end{array}$ & $M$ & $\begin{array}{c}22 \\
\text { months }\end{array}$ & Ward & & $\begin{array}{r}\mathrm{KP} \\
12\end{array}$ & $\mathrm{M}$ & 74 & ICU & \\
\hline
\end{tabular}


Table 3: Genotypes encountered amongst ESBL-producers

\begin{tabular}{llll}
\hline Genotype & $\begin{array}{l}\text { Escherichia } \\
\text { coli }\end{array}$ & $\begin{array}{l}\text { Klebsiella } \\
\text { pneumoniae }\end{array}$ & P-value \\
\hline blaTEM & $8(33.33 \%)$ & $18(75 \%)$ & $0.0001^{*}$ \\
blaSHV & $4(16.67 \%)$ & $22(91.67 \%)$ & $0.0001^{*}$ \\
blaCTX & $16(67 \%)$ & $24(100 \%)$ & $0.0001^{*}$ \\
\hline
\end{tabular}

${ }^{*}$ Chi-squared significance level $p<0.0001$; TEM, SHV and CTX were statistically significant for $E$. coli and $K$. pneumoniae genes, respectively $(p=0.000)$. However, CTX did not show any statistical difference with either $E$. coli or K. pneumoniae.

Table 4: Phenotypic characteristics of ESBL-producing Escherichia coli blood isolates, their antimicrobial resistance, and associated genes

\begin{tabular}{|c|c|c|c|}
\hline Lab ID & $\begin{array}{l}\text { Ward of } \\
\text { Isolation }\end{array}$ & $\begin{array}{l}\text { Types of } \\
\beta \text {-lactamases }\end{array}$ & Antimicrobial resistance pattern \\
\hline EC 1 & ward & CTX & AMK, AM, AUG, AZT, CAZ, PIME, CXM, CAX, CF, CIP, \\
\hline EC 2 & $\mathrm{ICU}$ & CTX & AM, AUG, AZT, CAZ, PIME, CXM, CAX, CTX, CF, CIP, GM, PI, FO. \\
\hline EC 3 & ward & CTX & AM, AUG, AZT, CAZ, PIME, CXM, CAZ, CTX, CF, PI \\
\hline EC 4 & ICU & CTX & AM, AZT, CAZ, PIME, CXM, CAZ, CTX, CF, CIP, PI \\
\hline EC 5 & Ward & NF & $\begin{array}{l}\text { AMK, AM, AUG, AZT, CAZ, PIME, CMX, CAX, CTX, CF, CIP, GM, } \\
\text { MER, PI, TO, LVF. }\end{array}$ \\
\hline EC 6 & Ward & SHV & AM, AZT, CAZ, PIME, CXM, CAX, CTX, CF, CIP, PI, LVF \\
\hline EC 7 & Ward & CTX, SHV & AM, AZT, CAZ, PIME, CXM, CAX, CTX, CF, CIP, GM, PI, TO, LVF. \\
\hline EC 8 & Ward & CTX, SHV & AM, AZT, CAZ, PIME, CXM, CAX, CTX, CF, CIP, GM, PI, LVF. \\
\hline EC 9 & ICU & $\begin{array}{l}\text { CTX, SHV, } \\
\text { TEM }\end{array}$ & $\begin{array}{l}\text { AMK, AM, AUG, AZT, CAZ, PIME, CMX, CAX, CTX, CF, CIP, GM, PI, } \\
\text { TO, LVF. }\end{array}$ \\
\hline EC 10 & ICU & CTX & AMK, AM, AZT, CAZ, PIME, CMX, CAX, CTX, CF, CIP, PI, LVF. \\
\hline EC 11 & Ward & NF & AMK, AM, AUG, AZT, CAZ, PIME, CMX, CAX, CTX, CF, CIP, GM, PI. \\
\hline EC 12 & Ward & TEM & $\begin{array}{l}\text { AMK, AM, AUG, AZT, CAZ, PIME, CMX, CAX, CTX, CF, CIP, PTZ, } \\
\text { PI, TO, LVF. }\end{array}$ \\
\hline \multicolumn{4}{|c|}{$\begin{array}{l}\text { AMK = amikacin, AM = ampicillin, AUG = amoxicillin/clavulanic acid, AZT = aztreonam, CAZ = ceftazidime, PIME } \\
=\text { cefepime }, \mathrm{CMX}=\text { cefuroxime, } \mathrm{CAX}=\text { ceftriaxone, } \mathrm{CTX}=\text { cefotaxime, } \mathrm{CF}=\text { cephalothin, } \mathrm{CIP}=\text { ciprofloxacin, } \mathrm{GM} \\
=\text { gentamicin, } \mathrm{MER}=\text { meropenem, } \mathrm{PTZ}=\text { piperacillin/tazobactam, TO = Tobramycin, LVF = levofloxacin, } \mathrm{PI}= \\
\text { piperacillin. } \mathrm{NF}=\text { not found }\end{array}$} \\
\hline
\end{tabular}

Table 5: Phenotypic characteristics of ESBL-producing $K$. pneumoniae blood isolates, their antimicrobial resistance and the associated genes

\begin{tabular}{|c|c|c|c|}
\hline Lab ID & $\begin{array}{l}\text { Isolation } \\
\text { ward }\end{array}$ & $\begin{array}{l}\text { Type of } \\
\beta \text {-lactamase }\end{array}$ & Antimicrobial resistance pattern \\
\hline KP 1 & Ward & CTX, SHV & AUG, AZT, CAZ, PIME, CMX, CAX, CTX, CF, CIP, GM, PT, TO, LVF. \\
\hline KP 2 & ICU & CTX, SHV, & AUG, AZT, CAZ, PIME, CMX, CAX, CTX, CF, CIP, GM, PT, TO, LVF. \\
\hline KP 3 & Ward & CTX, SHV, TEM & $\begin{array}{l}\text { AUG, AZT, CAZ, PIME, CMX, CAX, CTX, CF, CIP, GM, PTZ, PT, TO, } \\
\text { LVF. }\end{array}$ \\
\hline KP 4 & Ward & CTX, SHV, TEM & $\begin{array}{l}\text { AMK, AUG, AZT, CAZ, PIME, CMX, CAX, CTX, CF, CIP, GM, PTZ, } \\
\text { PT, TO, LVF. }\end{array}$ \\
\hline KP 5 & ICU & CTX, SHV, TEM & $\begin{array}{l}\text { AMK, AUG, AZT, CAZ, PIME, CMX, CAX, CTX, CF, CIP, GM, PTZ, } \\
\text { PT, TO, LVF. }\end{array}$ \\
\hline KP 6 & Ward & CTX, SHV & AUG, AZT, CAZ, PIME, CMX, CAX, CTX, CF, CIP, GM, PT, TO, LVF \\
\hline KP 7 & $\mathrm{ICU}$ & CTX, TEM & $\begin{array}{l}\text { AUG, AZT, CAZ, PIME, CMX, CAX, CTX, CF, CIP, GM, PTZ, PT, TO, } \\
\text { LVF. }\end{array}$ \\
\hline KP 8 & ICU & CTX, SHV, TEM & $\begin{array}{l}\text { AUG, AZT, CAZ, PIME, CMX, CAX, CTX, CF, CIP, GM, PTZ, PT, TO, } \\
\text { LVF. }\end{array}$ \\
\hline KP 9 & ICU & CTX, SHV, TEM & AUG, AZT, CAZ, PIME, CMX, CAX, CTX, CF, CIP, GM, PT, TO, LVF. \\
\hline KP 10 & Ward & CTX, SHV, TEM & AUG, AZT, CAZ, PIME, CMX, CAX, CTX, CF, CIP, GM, PT, TO, LVF. \\
\hline KP 11 & Ward & CTX, SHV, TEM & AUG, AZT, CAZ, PIME, CMX, CAX, CTX, CF, CIP, GM, PT, TO, LVF. \\
\hline KP 12 & ICU & CTX, SHV, TEM & $\begin{array}{l}\text { AUG, AZT, CAZ, PIME, CMX, CAX, CTX, CF, CIP, GM, PTZ, PT, TO, } \\
\text { LVF. }\end{array}$ \\
\hline
\end{tabular}




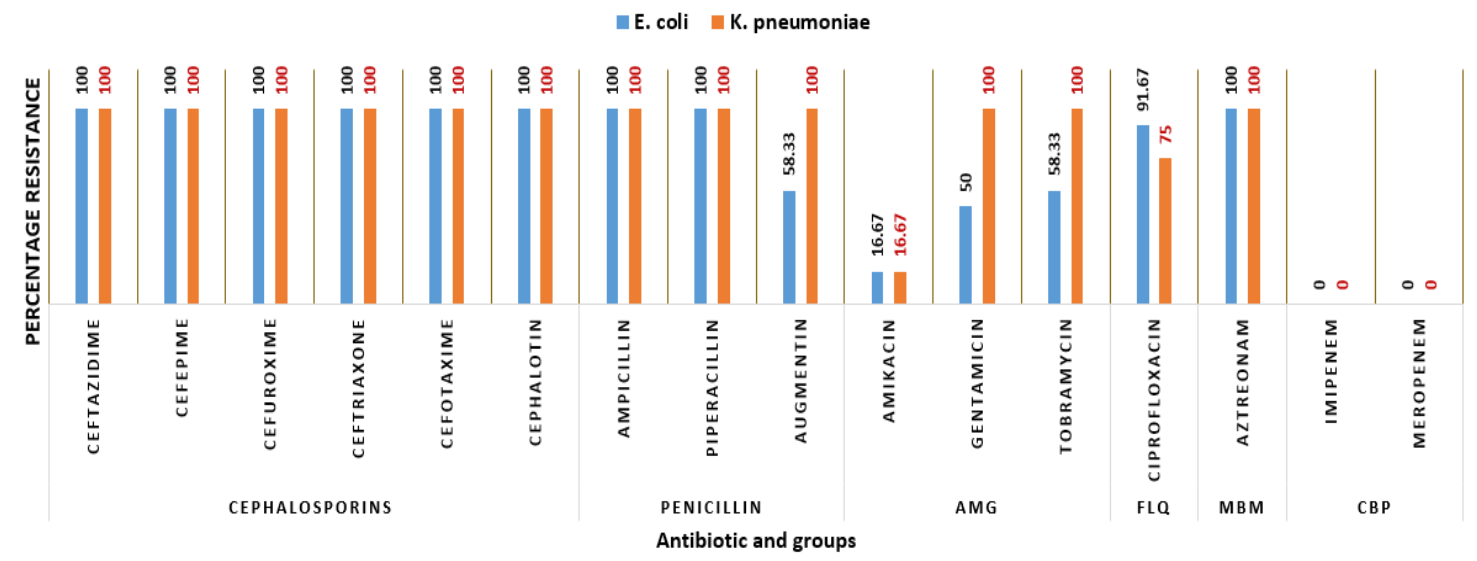

Figure 1: Antimicrobial resistance of ESBL-producing Escherichia coli and Klebsiella pneumoniae blood isolates against antibiotics groups. $A M G=$ aminoglycosides, $F L Q=$ fluoroquinolones, $M B M=$ monobactams, $C B P=$ carbapenems. With two-tailed test, $p=0.0580$ (differences not statistically significant)

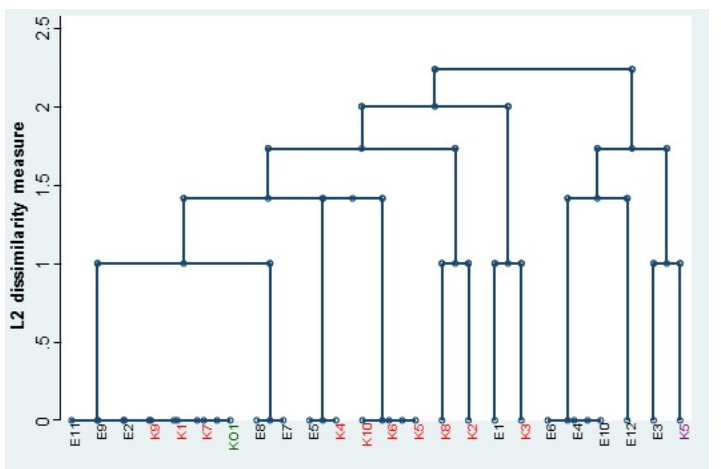

Figure 2: Dendrogram of cluster analysis of ESBLproducing blood isolates. Key: $\mathrm{E}=$ Escherichia coli; $\mathrm{K}=$ Klebsiella pneumoniae

\section{DISCUSSION}

This investigation has further highlighted the threat faced by clinicians in the treatment of patients in healthcare settings as a result of ESBL-KP and EBLS-EC BSIs due to the extensively high levels of antimicrobial resistance. High resistance such as was seen in the ESBL-KP and EBLS-EC BSIs in the present investigation indicates that there could be limited treatment options available to clinicians in healthcare settings [11]. Reports by the infectious Disease Society of America [25] listed ESBL-KP and ESBL-EC among the six MDR bacteria to which there is a need for urgent treatment options.

More than a decade later, that report remains valid, as is evident in the results of the present study with respect to antimicrobial susceptibility pattern exhibited by the ESBL-KP and EBLS-EC associated with BSIs. This implies that available therapeutic measures are grossly limited, and this could lead to an increase in treatment failures and an increase in death rates $[9,12]$. In a study of BSIs caused by ESBL-E in a tertiary hospital in New Zealand, Freeman et al [11] reported higher mortality in ESBL-E bacteremia than in the control cases, with one of the risk factors being exposure to antibiotic treatment. Although the present report did not include treatment outcomes, there will be a need for continuous and more detailed updates on ESBLproducing BSIs, for a much needed global and regional surveillance.

In terms of molecular analysis, the present findings show that cefotaximase (CTX-M), temoneira (TEM) and sulfhydryl variable (SHV) were associated with ESBL-KP and EBLS-EC BSIs. There were variabilities in percentages of TEM, SHV and CTX encountered by the ESBL$\mathrm{KP}$ and EBLS-EC associated with BSIs in this study, with the predominant gene being CTX. This is similar to the findings of Shahid et al [26]. Moreover, Scheuerman et al [24] reported that CTX-M was the most prevalent ESBL subtype identified in their study, while among the four classes of ESBLs, the A class TEM and SHV variants were the most-produced by Klebsiella species and $E$. coli. This suggests variations that could be attributed to regional differences [26]. Attention has been drawn to a global rise in the CTX-M-type ESBLs in community-acquired $E$ coli, as well as in nosocomial Klebsiella species [23], a view supported by other researchers [22]. Therefore, the present finding regarding 67 and $100 \%$ CTX expressed by EBLS-EC and ESBL$\mathrm{KP}$, respectively, in the BSIs are similar to those reported previously [22].

Resistance by ESBL-producing bacteria responsible for these BSIs can be attributed to the number of $\beta$-lactamase genes encountered in 
each bacterium, as shown in the results. The carriage of SHV $\beta$-lactamase by $92 \%$ of ESBL$\mathrm{KP}$ BSIs as seen in this investigation, as well as all isolates being CTX- $\beta$-lactamase producers, would explain the higher resistance against antimicrobials shown by them, relative to those of EBLS-EC BSIs. The high percentage carriage of the associated genes in the ESBL-KP BSIs in this investigation could be attributed to both chromosomal and extra-chromosomal factors. Similar views have been expressed in a previous study [26]. There were variations in the number of carriages of A class blatem, blashv, and blactx genotypes in each of the BSIs in this study. This contributed to the level of resistance by each of the ESBL-KP and ESBL-EC isolates in the present investigation.

In addition, the coexistence of different $\beta$ lactamase genes within an isolate for both bacterial species could point to a mechanism that may lead to resistance against different antimicrobials as previously expressed [22]. However, observations on co-existence of antimicrobial resistance genes vary. Sima et al [22] found that ESBL-producing $E$. coli from urine sample isolates had two or more ESBLs genes, with the most common being the CTX and TEM genotypes. Similarly, other findings [27] found TEM and CTX to be the most common genotypes associated with $E$. coli in Saudi Arabia. In this investigation, the CTX and TEM genotypes were also the most common among ESBL-EC BSIs, while the most common for ESBL-KP were the SHV and CTX genotypes. These findings highlight differences in resistance genes among the bacterial species, as earlier reported [23]. With only $25 \%$ of the isolates carrying multiple ESBL genes, there are possibilities of regional and geographical differences. Differences in gene carriage could also be due the types of specimens, as well as their origins (nosocomial or community). While the samples used by some researchers were from urine specimens $[23,25]$, the samples used in this study were from blood stream infections. Another contributory factor associated with multiple carriage of resistant genes could be the length of hospitalisation of patients in intensive care unit (ICU), which was more than 14 days [25].

Therefore, there is the possibility that the ESBL$\mathrm{KP}$ in the present investigation were nosocomial in origin. For treatment, the carbapenems remain the antibiotics of choice, since all ESBL producers in this investigation were sensitive to them. Moreover, another study [23] reported $8 \%$ resistance to the carbapenems, indicating that the carbapenems remain the antimicrobial of choice. On the other hand, with the dendrogram clustering results showing that both ESBL-EC and ESBL-KP BSIs were not of the same homologous group, there is a need to take this point into consideration when instituting treatment by healthcare providers, as had been suggested by previous other researchers [25]. In accordance with global recommendations for the monitoring and the reporting of antimicrobial resistance, this study serves as a guide for preventive measures aimed at mitigating BSIs in hospitals in the Kingdom of Saudi Arabia.

\section{CONCLUSION}

This study has revealed that blatem, blashv and blactx phenotypes are associated with ESBLproducing BSI resulting from $K$. pneumoniae and E. coli. All three genotypes were predominant in ESBL-KP than ESBL-EC. With all BSI isolates being sensitive to the carbapenems, this group of antibiotics could be the gold standard for the treatment of $K$. pneumoniae and $E$. coli infections.

\section{DECLARATIONS}

\section{Acknowledgement}

The authors would like to acknowledge the Deanship of Scientific Research at King Faisal University for the financial support under Nasher Track (Grant no. 186267).

\section{Conflict of interest}

No conflict of interest is associated with this work.

\section{Contribution of authors}

We declare that this work was done by the authors named in this article, and all liabilities pertaining to claims relating to the content of this article will be borne by the authors. Lorina I. Badger-Emeka developed the research concept and study design, participated in all laboratory experiments, and in collection and analysis of data, drafting of report, and final report preparation. Zainab Y. Al-Jaziri participated in collection of laboratory specimens, and was involved in molecular DNA extraction, and in final preparation of report. Naheed Kausar took part in bacteriological experiments, amplification of DNA products and final preparation of the report. Nora Ahmad Al-Muhainy was involved in collection of laboratory specimens, molecular DNA extraction, and preparation of the report. Edric Estrella 
carried put data analysis and final report preparation.

\section{Open Access}

This is an Open Access article that uses a funding model which does not charge readers or their institutions for access and distributed under the terms of the Creative Commons Attribution License (http://creativecommons.org/licenses/by/ 4.0) and the Budapest Open Access Initiative (http://www.budapestopenaccessinitiative.org/rea d), which permit unrestricted use, distribution, and reproduction in any medium, provided the original work is properly credited.

\section{REFERENCES}

1. Folasoge AA, Babatunde OM, Akinniyi A, John A, Joseph IO, Bukola WA, Agunlejika RA. A Multicenter Study of Beta-Lactamase Resistant Escherichia coli and Klebsiella pneumoniae Reveals High Level Chromosome Mediated Extended Spectrum $\beta$ Lactamase Resistance in Ogun State, Nigeria. Hindawi Publishing. Corporation. Interdiscip Perspect Infect Dis 2014; ID 819896.

2. Ndir A, Diop A, Faye PM, Cissé MF, Ndoye B, Astagneau $P$. Epidemiology and Burden of Blood stream Infections Caused by Extended-Spectrum Beta-Lactamase Producing Enterobacteriaceae in a Pediatric Hospital in Senegal. PLoS ONE 2016; 11(2): e0143729.

3. Seale AC, Blencowe $H$, Manu AA, Nair H, Bahl R, Qazi SA, Zaidi AK, Berkley JA, Cousens SN, Lawn JE. Estimates of possible severe bacterial infection in neonates in sub-Saharan Africa, south Asia, and Latin America for 2012: a systematic review and metaanalysis. Lancet Infect Dis 2014; 14: 731-741.

4. Buetti N, Atkinson A, Marschall J, Kronenberg A. Incidence of bloodstream infections: a nationwide surveillance of acute care hospitals in Switzerland 2008-2014. BMJ Open 2017; 7: e013665

5. Wilson J, Elgohari S, Livermore DM, Cookson B, Johnson A, Lamagni T, Chronias A, Sheridan E. Trends among pathogens reported as causing bacteraemia in England, 2004-2008. Clin Microbiol Infect 2011; 17:451458.

6. Nielsen SL, Pedersen C, Jensen TG, Gradel KO, Kolmos $H J$, Lassen AT. Decreasing incidence rates of bacteremia: a 9-year population-based study. J Infect 2014; 69: 51-59.

7. Skogberg K, Lyytikäinen O, Ollgren J, Nuorti JP, Ruutu P. Population-based burden of bloodstream infections in Finland. Clin Microbiol Infect 2012; 18: 170-176.

8. de Kraker ME, Jarlier V, Monen JC, Heuer OE, van de Sande N, Grundmann H. The changing epidemiology of bacteraemias in Europe: trends from the European Antimicrobial Resistance Surveillance System. Clin Microbiol Infect 2013; 19: 860-868.
9. Haque KN, Chagia AH, Shaheed MM. Half a Decade of Neonatal Sepsis, Riyadh, Saudi Arabia. J Trop Pediatr 1990; 36(1): 20-23.

10. Ozbak HA. Epidemiology of bloodstream infection in Saudi Arabia. AFR J Microbio Res 2018; 12(43): 973987.

11. Al-Otaibi FE, Bukhari EE, Badr M, Alrabiaa AA. Prevalence and risk factors of Gram-negative bacilli causing blood stream infection in patients with malignancy. Saudi Med J 2016; 37(9): 979-984.

12. Freeman JT, McBride SJ, Nisbet MS. Gamble GD, Williamson DA, Taylor SL, Holland DJ. Bloodstream infection with extended-spectrum beta-lactamaseproducing Enterobacteriaceae at a tertiary care hospital in New Zealand: risk factors and outcomes. Int J Infect Dis 2012; 16(5): 371-374.

13. Tumbarello $M$, Sanguinetti $M$, Montuori E, Trecarichi EM, Posteraro B, Fiori B, Citton R, D'Inzeo $T$, Fadda G, Cauda R, Spanu T. Predictors of mortality in patients with bloodstream infections caused by extendedspectrum-beta-lactamase-producing

Enterobacteriaceae: importance of inadequate initial antimicrobial treatment. Antimicrob Agents Chemother 2007; 51(6):1987-1994.

14. Sibhghatulla S, Jamale F, Shazi S, Syed M, Danish R, Mohammad AK. Prevalence of multidrug resistant and extended spectrum beta-lactamase producing Pseudomonas aeruginosa in a tertiary care hospital. Saudi J Biol Sci 2015; 22: 62-64.

15. Chaudhary U, Aggarwal R. "Extended spectrum $\beta$ lactamases (ESBL); an emerging threat to clinical therapeutics," Indian J Med Microbiol 2004; 22(2): 75 80.

16. Paterson DL, Bonomo RA. Extended-Spectrum $\beta$ Lactamases: a Clinical Update. Clin Microbiol Rev 2005; 657-686.

17. Kumar A, Ellis $P$, Arabi $Y$, Roberts $D$, Light $B$, Parrillo JE, Dodek $P$, Wood G, Kumar A, Simon D, et al. Initiation of inappropriate antimicrobial therapy results in a fivefold reduction of survival in human septic shock. Chest 2009; 136(5): 1237-1248.

18. Clinical Laboratory Standards Institute, Methods for Dilution Antimicrobial Susceptibility Testing for Bacteria That Grows Aerobically. Ninth Edition (M07-A9), Clinical Laboratory Standards Institute, Wayne, Pa, USA, 2012a

19. Kaur J, Chopra S, Sheevani, Mahajan G. Modified Double Disc Synergy Test to Detect ESBL Production in Urinary Isolates of Escherichia coli and Klebsiella pneumoniae. J Clin Diagn Res 2013; 7(2): 229-233.

20. Clinical Laboratory Standards Institute, Performance Standards for Antimicrobial Susceptibility Testing: 22nd International Supplement. (M100-S22), Clinical Laboratory Standards Institute, Wayne, Pa, USA, $2012 b$.

21. Yazdi MKS, Mohammad MSD, Hedroosha MAM, Ailar S, Jalil FM, Lari AR, Eshraghian MR, Saneiee AF, Abdar $M H$, Bakhtiari R. Molecular detection of TEM broad

Trop J Pharm Res, June 2020; 19(6): 1292 
spectrum Blactamase in clinical isolates of Escherichia coli. Afr J Biotechnol 2011; 10(46): 9454-9458,

22. Mulvey MR, Bryce $E$, Boyd $D$, Ofner-gostini $M$, Christianson S, Simor AE, Paton S. Ambler Class A Extended-Spectrum Beta-Lactamase-Producing Escherichia coli and Klebsiella spp. in Canadian Hospitals. Antimicrob Agents Chemother 2004; 48(4): 1204-1214.

23. Sima SS, Mehdi G, Fattaneh, S. "Relation between bla TEM, bla SHV and bla CTX-M genes and acute urinary tract infections". J Acute Dis 2016; 5(1): 71-76.

24. Harris PNA, Tambyah PA, Paterson DL. $\beta$-lactam and $\beta$ lactamase inhibitor combinations in the treatment of extended-spectrum $\beta$-lactamase producing Enterobacteriaceae: time for a reappraisal in the era of few antibiotic options? Lancet Infect Dis 2015; 15: 475-485.

25. Scheuerman O, Schechner V, Carmeli Y, GutiérrezGutiérrez B, Calbo E, Almirante B, Viale PL, Oliver A, Ruiz-Garbajosa $P$, Gasch $O$, Gozalo $M$, et al. Comparison of Predictors and Mortality Between Bloodstream Infections Caused by ESBL-Producing
Escherichia coli and ESBL-Producing Klebsiella pneumoniae. Infect Control Hosp Epidemiol. 2018; 39(6): 660-667.

26. Talbot GH, Bradley J, Edwards JE, Gilbert D, Scheld M, Bartlett JG. Bad bugs need drugs: an update on the development pipeline from the Antimicrobial Available Task Force of the Infectious Diseases Society of America. Clin Infect Dis 2006; 42: 657-668.

27. Shahid M, Singh A, Sobia F, Rashid M, Malik A, Shukla I, Khan HM. blaCTX-M, blaTEM, and blaSHV in Enterobacteriaceae from North-Indian tertiary hospital: high occurrence of combination genes. Asian Pac $J$ Trop Med 2011; 4(2): 101-105.

28. Oteo J, Perez-V 'AM, Campos J. Extended-spectrum [beta] lactamase producing Escherichia coli: changing epidemiology and clinical impact. Curr Opin Infect Dis 2010; 23(4): 320-326.

29. Hassan $H$, Abdalhamid B. Molecular characterization of extended spectrum beta-lactamase producing Enterobacteriaceae in a Saudi Arabian tertiary hospital. J Infect Dev Ctries 2014; 8(3): 282-288. 